\title{
37. PRELIMINARY ORGANIC GEOCHEMISTRY OF LAMINATED VERSUS NONLAMINATED SEDIMENTS FROM HOLES 479 AND 480, DEEP SEA DRILLING PROJECT LEG 641
}

\author{
Bernd R. T. Simoneit, ${ }^{2}$ Institute of Geophysics and Planetary Physics, University of California-Los Angeles, \\ Los Angeles, California
}

\begin{abstract}
Laminated and nonlaminated sediments from Holes 480 and 479 have been analyzed for potential differences in the composition of organic matter. Their lipid composition is very similar and indicates a primary autochthonous microbial origin and some influx of allochthonous higher-plant detritus. The nonlaminated sections contain relatively more terrigenous plant wax detritus versus autochthonous residues and a much greater amount of perylene than the laminated sections.
\end{abstract}

\section{INTRODUCTION}

Holes 479 and 480 were cored $6 \mathrm{~km}$ apart on the Guaymas Slope (for location, see Simoneit's introduction to shore-based studies, this volume, Pt. 2). The sediments consisted primarily of laminated and nonlaminated, muddy diatomaceous ooze with some rare interbedded sands and thin diagenetic-dolomite layers (Curray et al., 1979). These laminated sediments are probably varves, resulting from the interaction of two seasonal events: the summer rains that introduce terrigenous clays to the region and diatom blooms caused by upwelling from northwest winter winds (Curray et al., 1979; Schrader et al., 1980). The preservation of laminated sediment sections indicates oxygen depletion in the bottom waters.

Samples for this study were chosen from Hole 480 to examine any potential differences in the composition of the organic matter in laminated versus nonlaminated sections. A sample of driftwood and a laminated sediment sample, both from Hole 479, were also analyzed for comparison.

\section{METHODS}

The samples from Hole 480 were taken by scraping a fresh surface of split core. Each $10-\mathrm{cm}$ interval represents a maximum of $100 \mathrm{y}$. of sedimentation. The small samples $(0.5-2 \mathrm{~g})$ were freeze dried and then extracted repeatedly with a mixture of chloroform and methanol (1:1) using ultrasonication. The extracts were concentrated on a rotary evaporator and then subjected to column chromatography (microscale) on silica gel; hexane was the eluent. The total hydrocarbon fractions were collected, concentrated, and analyzed by gas chromatography (GC) and GC/mass spectrometry (GC/MS). After esterification, the extract from Sample 479-29-5, 114-116 cm was separated by thin-layer chromatography; hydrocarbons and fatty-acid esters were then analyzed.

The GC analyses were carried out on a Hewlett-Packard 5840 gas chromatograph using a $25 \mathrm{~m} \times 0.20 \mathrm{~mm}$ fused-silica capillary column coated with SP-2100. The chromatograph was programmed from 35 to $280^{\circ} \mathrm{C}$ at $4^{\circ} \mathrm{C}$ per min.; He was the carrier gas.

\footnotetext{
${ }^{1}$ Curray, J. R., Moore, D. G., et al., Init. Repts, DSDP, 64: Washington (U.S. Govt. Printing Office). 97331.
}

The GC/MS analyses were carried out on a Finnigan 4000 quadrupole mass spectrometer interfaced directly to a Finnigan 9610 gas chromatograph equipped with a $30 \mathrm{~m} \times 0.25 \mathrm{~mm}$ fused-silica capillary column coated with SE-54. The GC conditions for the GC/MS analyses were the same as those for the analytical GC system. MS data were acquired and processed with a Finnigan-Incos 2300 data system.

\section{RESULTS AND DISCUSSION}

The sample descriptions and analytical results are given in Table 1. The samples from Hole 480 were too small for the usual geochemical parameter analyses; thus, only the hydrocarbon data are reported here.

The total-lipid yields (Table 1) are high, and larger concentrations occur in the laminated (varved) sections of Hole 480 . The same is true for the total hydrocarbon yields. The $n$-alkane distributions are quite similar; only subtle differences exist between the laminated (Fig. 1A, C) and nonlaminated (Fig. 1B, D) samples. The $n$-alkanes range from $\mathrm{C}_{12}$ to $\mathrm{C}_{33}$, and usually have three maxima-at $\mathrm{C}_{15}, \mathrm{C}_{21}$ to $\mathrm{C}_{23}$, and $\mathrm{C}_{29}$-and a strong oddto-even carbon number predominance $>\mathrm{C}_{23}$. The homologs $<\mathrm{C}_{23}$ represent autochthonous marine lipids, where undegraded microbial residues $<\mathrm{C}_{19}$ and degraded algal material in the region of $\mathrm{C}_{19}$ to $\mathrm{C}_{23}$ occur (Simoneit, 1975, 1978a, in press). The homologs $>C_{23}$ with the odd-carbon-number predominance represent an allochthonous component derived from terrestrial higher-plant wax (Simoneit, 1975, 1978a,b). The terrigenous alkanes occur in about equal absolute amounts in both types of samples, but their relative proportions versus the microbial residues are greater in nonlaminated samples. This indicates that, during a depositional period that produces the nonlaminated sequences, the terrigenous influx of mineral detritus is high, but the terrestrial organic matter associated with the detritus is lower or about the same.

The isoprenoid hydrocarbons occur in significant amounts (Fig. 1), but the $\mathrm{Pr} / \mathrm{Ph}$ ratios of the Hole 480 samples are $>1$ (Table 1). All samples contain elemental sulfur, and the amounts do not correlate with the laminated versus nonlaminated sections. These data are inconclusive regarding partially euxinic conditions caused by the rapid sedimentation (Didyk et al., 1978). The 
Table 1. Sample descriptions and analytical results for core material, Holes 479 and 480.

\begin{tabular}{|c|c|c|c|c|c|c|c|c|c|c|}
\hline \multirow{2}{*}{$\begin{array}{c}\text { Sample }{ }^{\mathrm{a}} \\
\text { (interval in } \mathrm{cm} \text { ) }\end{array}$} & \multirow{2}{*}{$\begin{array}{l}\text { Sub-bottom } \\
\text { Depth } \\
\text { (m) }\end{array}$} & \multirow[b]{2}{*}{ Lithology } & \multirow{2}{*}{$\begin{array}{c}\text { Total } \\
\text { Lipids } \\
(\mu \mathrm{g} / \mathrm{g})^{\mathrm{b}}\end{array}$} & \multirow{2}{*}{$\begin{array}{c}\text { Total } \\
\text { HC } \\
(\mu \mathrm{g} / \mathrm{g})^{\mathrm{b}}\end{array}$} & \multicolumn{2}{|r|}{$n$-alkanes } & \multirow[b]{2}{*}{$\mathrm{Pr} / \mathrm{Ph}$} & \multirow{2}{*}{$\begin{array}{l}\text { Perylene } \\
(\mu g / g)^{b}\end{array}$} & \multicolumn{2}{|c|}{ Kerogen } \\
\hline & & & & & $\mathrm{CPI}^{\mathrm{c}}$ & Maxima $^{\mathrm{d}}$ & & & $\mathrm{H} / \mathrm{C}, \mathrm{N} / \mathrm{C}^{\mathrm{e}}$ & ${ }^{13} \mathrm{C}\left(\%_{s}\right)^{\mathrm{f}}$ \\
\hline $480-2-3,21-30$ & 8.0 & $\begin{array}{l}\text { laminated } \\
\text { diatom ooze }\end{array}$ & 1327 & 435 & 1.3 & $15,21,29$ & 1.4 & 0.24 & - & - \\
\hline $480-3-3,107-119$ & 13.7 & $\begin{array}{l}\text { nonlaminated } \\
\text { diatom ooze }\end{array}$ & 976 & 370 & 1.5 & $15,22,29$ & 1.7 & 1.2 & - & - \\
\hline $480-19-1,58-59$ & 90.9 & $\begin{array}{l}\text { laminated } \\
\text { diatom ooze }\end{array}$ & 1316 & 490 & 1.4 & $15,21,27$ & 1.1 & 0.41 & - & - \\
\hline $480-19-1,130-150$ & 91.7 & $\begin{array}{l}\text { nonlaminated } \\
\text { diatom ooze }\end{array}$ & 748 & 250 & 1.7 & $15,17,22,29$ & 1.3 & 3.2 & - & - \\
\hline $479-9-2,28$ & 71.3 & wood & 800 & 56 & 2.21 & $19,22,29$ & 0.83 & n.d. & $\begin{array}{l}0.70 \\
(0.013)\end{array}$ & -23.4 \\
\hline $479-29-5,114-116$ & 266.7 & $\begin{array}{l}\text { laminated } \\
\text { diatom ooze }\end{array}$ & 490 & 64 & 1.6 & $17,29,31$ & 0.9 & 2.0 & $\begin{array}{l}1.20 \\
(0.046)\end{array}$ & -19.9 \\
\hline
\end{tabular}

Note: n.d. $=$ not detected; dash $=$ not determined.

a All samples are late Quaternary.

b Weights based on dry sediment.

Carbon preference index summed from $\mathrm{C}_{10}-\mathrm{C}_{35}$, odd/even

The dominant homolog is in italic.

e Determined by Microanalytical Laboratory, Department of Chemistry, University of California-Berkeley; N/C in parentheses.

${ }^{f}$ Reported versus PDB standard.

$\mathrm{Pr} / \mathrm{Ph}>1$ could however be caused by the immaturity of the organic detritus, which could invert to $<1$ on further maturation (e.g., Sample 479-29-5, 114-116 cm from greater sub-bottom depth; Fig. 1F).

Perylene $\left(\mathrm{C}_{20} \mathrm{H}_{12}\right)$ occurs in higher concentrations in the nonlaminated sequence (Table 1). This compound has been found in many euxinic sediments and appears to be another indicator of oxygen depletion in depositional environments (e.g., Simoneit, 1978a, 1978b; Simoneit and Mazurek, in press; Louda and Baker, in press). Whether it is a terrigenous marker or an autochthonous product is still a matter of debate and investigation.

The molecular markers, such as steroid and triterpenoid residues from autochthonous sources, are not detectable; however, diterpenoid residues from terrestrial resinous plants occur in minor amounts and at higher concentrations and diversity in the nonlaminated sections. The diterpenoid residues comprise retene, dehydroabietic acid, dehydroabietane, and minor amounts of dehydroabietin and methylethylphenanthrene (Simoneit, 1977). These compounds probably entered this sedimentary environment as resin microparticles.

The kerogens from Hole 480 are immature and of primarily marine origin (Peters and Simoneit, this volume). The analysis also indicates a difference in kerogen constitution for the laminated, euxinic (high hydrogen index/low oxygen index) versus the nonlaminated, oxic sequences (i.e., low hydrogen index/high oxygen index; Peters and Simoneit, this volume, Pt. 2).

The wood sample (479-9-2) had significant lipid and hydrocarbon contents (Table 1). The $n$-alkanes (Fig. 1E) primarily consist of plant wax ( $>\mathrm{C}_{24}$ ) and a lesser component of autochthonous material. Once sedimented, the autochthonous lipids were probably absorbed from the surroundings by the lignite, and the plant-wax residues were brought in with the fragment. The $\mathrm{H} / \mathrm{C}$ of the kerogen (extracted, demineralized residue) is 0.70 , the $\mathrm{N} / \mathrm{C}$ is 0.013 , and the $\delta^{13} \mathrm{C}$ is $-23.4 \%$ (Table 1). Except for $\mathrm{H} / \mathrm{C}$, these values do not indicate an origin from peat or vascular plant detritus $\left(\mathrm{C}_{3}\right.$ or Calvin cycle), where typical data are in the following ranges: $\mathrm{H} / \mathrm{C}=1.0, \mathrm{~N} / \mathrm{C}=0.03-0.06$, and $\delta^{13} \mathrm{C}=-27--28 \%$ 。
(Stuermer et al., 1978). For $\mathrm{C}_{4}$ plants (Hatch-Slack cycle), the $\delta^{13} \mathrm{C}$ range from -13 to $-23 \%$ (Galimov, 1980). This sample may represent a primary fragment of a $C_{4}$ plant or a highly oxidized coal fragment $\left(\mathrm{C}_{3}\right.$ plant $)$, where the light carbon isotopes have been preferentially removed, and/or the terrigenous organic matter was diluted with autochthonous marine detritus during preservation and coalification.

Sample $479-29-5,114-116 \mathrm{~cm}$ is about 267 meters sub-bottom, and is immature and unaltered. The lipid yield is high, and the $n$-alkanes (Fig. $1 \mathrm{~F}$ ) exhibit a bimodal distribution, ranging from $\mathrm{C}_{10}$ to $\mathrm{C}_{35}$ with maxima at $\mathrm{C}_{17}$ and $\mathrm{C}_{31}$. The homologs $>\mathrm{C}_{27}$ with the strong odd-to-even carbon number predominance are derived from allochthonous plant wax. The homologs $<\mathrm{C}_{24}$ are from autoch thonous microbial sources (Simoneit, 1975, $1978 \mathrm{a}$, in press). The $\mathrm{Pr} / \mathrm{Ph}$ is less than one, and perylene and elemental sulfur are present, indicating partially euxinic paleoenvironmental conditions of sedimentation (Didyk et al., 1978). The distribution of $n$ fatty acids is bimodal, with maxima at $\mathrm{C}_{16}$ and $\mathrm{C}_{26}$ and a strong even-to-odd carbon-number predominance, typical for biogenic sources (Fig. 1G). The homologs $>C_{21}$ are derived from terrigenous plant wax, and those $<\mathrm{C}_{20}$ are from autochthonous microbial sources (Simoneit, 1975, 1978a).

The molecular markers confirm this sample's immaturity and primarily consist of triterpenoid, steroid, and diterpenoid residues. The triterpenoids (Fig. 1H) comprise the $17 \beta(\mathrm{H})$-hopane series $\left(\mathrm{C}_{27}, \mathrm{C}_{29}-\mathrm{C}_{32}\right)$, lesser amounts of $17 \alpha(\mathrm{H})$-hopanes, hop-17(21)-ene, and isohop-13(18)-ene. These compounds are of an autochthonous marine origin and are geologically immature (Ourisson et al., 1979; Simoneit and Kaplan, 1980; Dastillung and Albrecht, 1976). The steroid residues in the hydrocarbon fraction consist of ster-2-enes and ster-4-enes (in nearly equal proportions), diasterenes, and a minor amount of steranes. They range from $\mathrm{C}_{26}$ to $\mathrm{C}_{30} ; \mathrm{C}_{27}$ is the dominant homolog in all cases. The inferred source of these compounds is autochthonous microbial residue in the early stages of diagenesis (Huang and Meinschein, 1979; Simoneit, 1978a; Simoneit and Philp, this volume, Pt. 2). The diterpenoid residues occur primarily as 

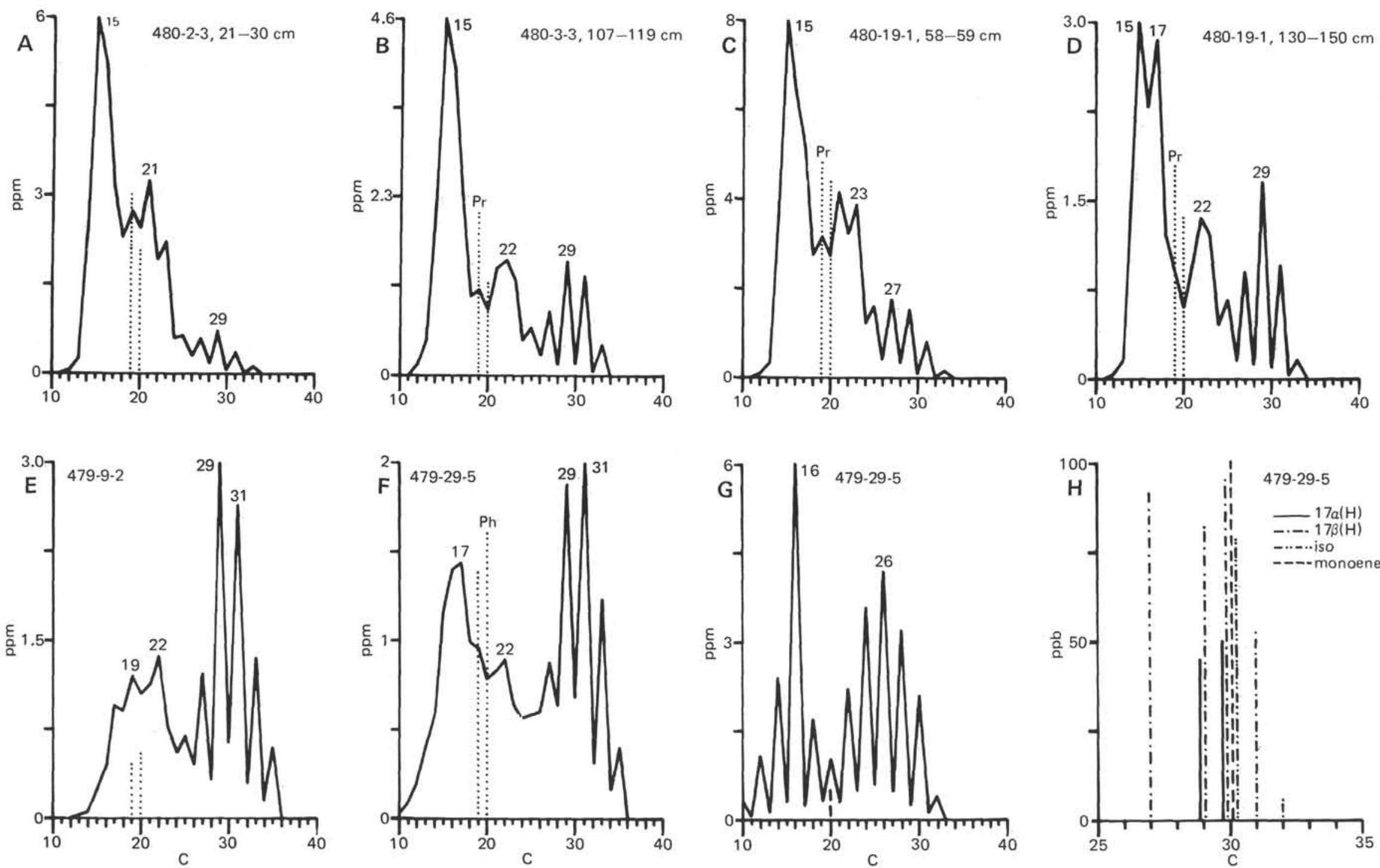

Figure 1. Distribution diagrams for various compound series, Holes 479 and 480. $n$-Alkanes [dotted line indicates isoprenoids]: A. Sample 480-2-3, 21-30 cm (laminated); B. Sample 480-3-3, 107-119 cm (nonlaminated); C. Sample 480-19-1, 58-59 cm (laminated); D. Sample 480-19-1, 130-150 cm (nonlaminated); E. Sample 479-9-2, 28 cm (driftwood); F. Sample 479-29-5, 114-116 cm. $n$-fatty acids [dashed line indicates dehydroabietic acid]: G. Sample 479-29-5, 114-116 cm. Triterpenoids: H. Sample 479-29-5, 114-116 cm. 
dehydroabietic acid (Fig. 1G) and retene and dehydroabietin at low concentrations, indicating a minor influx from terrigenous resinous plants (Simoneit, 1977).

The kerogen of this sample has been analyzed by Curie point pyrolysis (Simoneit and Philp, this volume), and the data indicate that it is of an unaltered marine origin. The pyrolysis product pattern is similar to that observed in kerogens from the Cariaco Trench (van de Meent et al., 1980) and Walvis Bay (Namibia) (Simoneit and Philp, this volume).

\section{CONCLUSIONS}

The laminated and nonlaminated sections have similar lipid compositions, but differ in their absolute concentrations of compound groups. In the nonlaminated sections, the terrigenous plant-wax residues are more concentrated than the autochthonous marine components. Perylene is also more concentrated (by a factor of nearly five) in those sections. These data can be interpreted as follows: (1) A greater influx occurred during the homogeneous sedimentation and consisted of terrigenous mineral detritus lower in lipids; however, the overall terrestrial lipid influx remained approximately constant. (2) The nonlaminated sections could also be a result of partially oxic conditions in the water column. The slightly more refractive waxes would thus remain in a zone with a slower overall sedimentation rate, whereas laminated sections would be deposited in more anoxic waters, which are the result of higher algal productivity and more rapid sedimentation.

This terrigenous influence is further substantiated by the kerogen data and the organic composition of the driftwood fragment.

\section{ACKNOWLEDGMENTS}

I thank Dana Blumfield and Dara Blumfield for technical assistance, E. Ruth for GC/MS data acquisition, and Monica A. Mazurek and Dr. Kerry Kelts for reviewing the manuscript. Contribution 2133 of the Institute of Geophysics and Planetary Physics, UCLA.

\section{REFERENCES}

Curray, J. R., Moore, D. G., Aguayo, J. E., et al., 1979. Leg 64 seeks evidence on development of basin in the Gulf of California. Geotimes, 24(7):18-20.
Dastillung, M., and Albrecht, P., 1976. Molecular test for oil pollution in surface sediments. Mar. Poll. Bull., 7:13-15.

Didyk, B. M., Simoneit, B. R. T., Brassell, S. C., et al., 1978. Geochemical indicators of palaeoenvironmental conditions of sedimentation. Nature, 272:216-222.

Galimov, E. M., 1980. $\mathrm{C}^{13} / \mathrm{C}^{12}$ in kerogen. In Durand, B. (Ed.), Kerogen, Insoluble Organic Matter from Sedimentary Rocks: Paris (Editions Technip), pp. 271-299.

Huang, W.-Y., and Meinschein, W. G., 1979. Sterols as ecological indicators. Geochim. Cosmochim. Acta, 43:739-745.

Louda, J. W., and Baker, E. W., in press. Geochemistry of tetrapyrrole, carotenoid and perylene pigments in sediments from the San Miguel Gap (Site 467) and Baja California Borderlands (Site 471): DSDP/IPOD Leg 63. In Haq, B., Yeats, R. S., et al., Init. Repts. $D S D P, 63$ : Washington (U.S. Govt. Printing Office).

Ourisson, G., Albrecht, P., and Rohmer, M., 1979. The hopanoids. Paleochemistry and biochemistry of a group of natural products. Pure Appl. Chem., 51:709-729.

Schrader, H., Kelts, K., Curray, J., et al., 1980. Laminated diatomaceous sediments from the Guaymas Basin Slope (Central Gulf of California): 250,000-year climate record. Science, 207:1207-1209.

Simoneit, B. R. T., 1975. Sources of organic matter in oceanic sediments [Ph.D. dissert.]. University of Bristol, England. , 1977. Diterpenoid compounds and other lipids in deepsea sediments and their geochemical significance. Geochim. Cosmochim. Acta, 41:463-476.

1978a. The organic chemistry of marine sediments. In Riley, J. P., and Chester, R. (Eds.), Chemical Oceanography, 2nd ed. (Vol. 7): New York (Academic), 233-311.

, 1978b. Organic geochemistry of terrigenous muds and various shales from the Black Sea, DSDP Leg 42B. In Ross, D., Neprochnov, Y., et al., Init. Repts. DSDP, 42, Pt. 2: Washington (U.S. Govt. Printing Office), 749-753.

in press. The composition, sources, and transport of organic matter to marine sediments-The organic geochemical approach. In Thompson, J. A. J. (Ed.), Proceedings of the Symposium on Marine Chemistry into the Eighties: Ottawa (National Research Board of Canada).

Simoneit, B. R. T., and Kaplan, I. R., 1980. Triterpenoids as molecular markers of paleoseepage in Recent sediments of the Southern California Bight. Mar. Environ. Res., 3:113-128.

Simoneit, B. R. T., and Mazurek, M. A., in press. Organic geochemistry of sediments from the Southern California Borderland, DSDP/ IPOD Leg 63. In Haq, B., Yeats, R. S., et al., Init. Repts. DSDP, 63: Washington (U.S. Govt. Printing Office).

Stuermer, D. H., Peters, K. E., and Kaplan, I. R., 1978. Source indicators of humic substances and protokerogen: Stable isotope ratios, elemental compositions and electron-spin resonance spectra. Geochim. Cosmochim. Acta, 42:989-997.

van de Meent, D., Brown, S. C., Philp, R. P., et al., 1980. Pyrolysis high resolution gas chromatography and pyrolysis gas chromatography-mass spectrometry of kerogens and kerogen precursors. Geochim. Cosmochim. Acta, 44:999-1013. 